\title{
Some Tendencies in Constitution Making
}

A most notable phenomenon in government during the last century and a quarter has been the adoption by most of the nations of the world of written constitutions. The work of the framers of our federal constitution has served as an inspiration and example to subsequent political thinkers and has resulted in the practical remoulding of most of the old governments and the establishment of governments of the modern type even in Africa and Asia. In Europe, save in England, in Hungary and in Italy, the fundamental law of the state exists in the form of written constitutions; in all the other continents, the new governments rest on the same sort of organic instruments. ${ }^{1}$ England alone, among the greater nations, rests her constitutional system upon unwritten law and custom. Of course, this does not mean that much of England's constitution may not be found in statutes, written orders, judicial decisions, and other writings. But both in spirit and substance, the English constitution depends for the most part upon custom and tradition. The Cabinet itself,- the controlling executive and important legislative department of the state,--is an extra-legal body; it owes its existence to custom rather than to legislation. And indeed, though perhaps in less degree the same may be said of Parliament itself. ${ }^{2}$

Though we are accustomed to consider ourselves a new and youthful country, in fact, within the territory of the written constitution we are the oldest of nations: Practically all governments as they existed when the constitutional convention of 1787 met at Philadelphia have simce that date been remade upon the Anglo-American model. As Mr. Hannis Taylor has pointed out, ${ }^{3}$ while the field of private law is being conquered by the Roman

I Bryce, Flexible and Rigid Constitutions, in Studies in History and Jurisprudence, p. 139.

2 Bryce, ubi supra, p. 134. On foreign constitutions, see Bourgeaud, Origin and Development of State Constitutions, 7 Pol. Sci. Quarterly, 613 .

3 The Science of Jurisprudence, Preface, p. XIV; 1 Virginia Law Review, 1 (Oct. 1913). 
law, the field of public law is more and more being taken possession of by the English ideas of government as wrought out in our federal constitution. And it has been the rigid type of the United States constitution, rather than the flexible type of the British constitution, that has served as the conquering force. The distinction between the rigid and the flexible constitution is, it is true, not ideally co-existent with that between the written and the unwritten one. ${ }^{4}$ The flexible constitution might be in writing, while the rigid constitution might be an unwritten one,the conservatism of the dominant forces in the state affording the inertia which the mere form of a written constitution provides. But, in fact, the unwritten constitution with which we are most familiar,--that of the United Kingdom of Great Britain and Ireland-is the most elastic and the most easy of amendinent,witness the recent amendment by which the powers of the House of Lords were materially curtailed. And on the other hand, the federal constitution of the United States is of all national constitutions the most inflexible, in other words, the most diffcult of amendment. The former depends entirely upon public opinion for its support, the latter trusts more to the mertia of the mass of the people to preserve it.

It was almost inevitable that the constitution of the United States should have been a written one of the rigid type. In its inception it was a treaty between sovereign states, and it still partakes of that character. Indeed, it is hardly conceivable that a federal state, as distinguished from a simple one, could exist without a written organic law strictly defining the boundaries between the central power and the constituent states.

Not only, however, did the nature of the compact practically predetermine the character of the constitution that would issue as a result of the deliberations of the convention of I787. The written constitution which that body submitted to the colonies for their ratification was the legitimate offspring of the constitutions of the individual colonies. Every delegate to that convention

* To Mr. Bryce, in the essay previously referred to, is due the suggestion of the classification of constitutions into "rigid" and "flexible." The suggestion was made in his original lecture on the subject in 1884, the basis of the later essay. President Lowell has criticized this distinction on the ground that the distinction between constitution making and ordinary legislation is so slight under some constitutions as to make it of little value. Lowell, Government of England, vol. I, p. 3. But, generally, there is such distinction recognizable. 
was already familiar with such formal statements of fundamental law, and many had already taken part in the drafting of organic instruments for their colonies. For, during the period between I776 and 1787 all the colonies, save two, had adopted new constitutions.

That these local constitutions should have been formal statements is, in turn, a natural outgrowth of prior conditions. The original frame of the charter governments of the colonies had accustomed people to the habit of stating their fundamental public law in systematic form. They were used to finding their rights and liberties and the nature and organs of their government defined in written charters, the direct grants of the Crown or of trading companies chartered by the Crown. And, more particularly in case of the Puritan colonists, they seem to have been possessed of what amounted alınost to a passion for stating principles of government and conduct in written form. The Solemn Covenant of the troublous times of Charles I and the unsuccessful attempt of the Long Parliament to adopt a Charter of Government will occur at once to the mind. And the person curious im such matters might with interest speculate upon the question as to how far this Puritan habit, itself perhaps the result of the study of the theocratic state described in the Pentateuch, influenced the currents of seventeenth and eighteenth century political thought. And such a person might trace some connection between the Puritan habit of looking to a written code of law and morality and the practice of such un-puritanical men as Franklin and Washington, who kept formal debit and credit accounts of their moral characters. ${ }^{5}$

Whatever the reasons, however, the fact remains that at the time when the federal constitution was adopted, every colony already had a written constitution of a more or less rigid type, and that ever since every state in the Union has had and now has a similar organic law. Indeed, it has been assumed as a matter of course that a state must have a formal statement of its

\footnotetext{
5 See, upon the general subject of the early state constitutions, Morey, The Genesis of Written Constitutions, 1 Am. Acad. Pol. \& Soc. Sci. 529; Jameson, Introduction to the Study of the Constitutional and Political History of the States, 4 John Hopkins University Studies, 185; Morey, First State Constitutions, 4 Am. Acad. Pol. \& Soc. Sci. 201; Webster, Comparative Study of the State Constitutions of the American Revolution, 9 Am. Acad.' Pol. \& Soc. Sci. 380; Schouler, Early State Constitutions, in "Constitutional Studies."
} 
framework and principles of government. The practice of Congress in admitting new states to the Union requires that the proposed state adopt and ratify a constitution as a condition precedent to admission, ${ }^{6}$ and it has been intimated by the United States Supreme Court, though by way of dictum, that a written constitution is a necessary part of that republican form of government which the United States guarantees to the several states.?

As to the respective merits of the rigid and of the flexible constitution, it is not necessary here to speak, ${ }^{8}$ nor is it within the scope of this paper to discuss suggested changes in the federal constitution, nor even inprovements in that of the state. It does, however, seem useful to call attention to certain facts and tendencies in constitutional developinent, inore particularly with reference to the constitution of California, which may suggest practical reform in the general scheme of constitution making. And this again requires us to speak a little more of the history of the local constitutions.

The constitutions adopted by the colonies between 1776 and I787 were quite simple. That of Massachusetts, adopted in I770, in large part the work of John Adams, may serve as an example of the sort of organic law which the framers of the federal constitution had before their eyes. ${ }^{9}$ It is interesting, in view of the perhaps exaggerated importance which a student of political or legal affairs is apt to attribute to merely formal arrangements, that the Commonwealth still manages to be tolerably well governed under this very old fashioned instrument, ordained "to the end it may be a governinent of laws and not of inen."10 But does not Bagehot say that the people of Massachusetts would be well governed under any constitution, however bad? Whether good or bad, however, the constitution of 1780 still remains, with

61 Willoughby, Constitutional Law of the United States, 320-323.

7 State of Texas v. White, (1868) 7 Wall. 700; 1 Thayer's Cases on Constitutional Law, 302, 306 (per Chase, C. J.)

8 For the relative merits of the two, see the essay, previously quoted, by Mr. Bryce, (now Viscount Bryce), in his Studies in History and Jurisprudence, pp. 134-213, upon Flexible and Rigid Constitutions, and the Essay by the late Thomas M. Cooley, Comparative Merits of Written and Prescriptive Constitutions, 23 Am. L. Rev. 311, 2 Harv. Law Rev. 341.

o Thorpe, American Charters, Constitutions and Organic Laws, vol. 3, pp. 1888-1923.

10 Constitution or Form of Government for the Commonwealth of Massachusetts Part the First, Article XXX. 3 Thorpe, 1893. 
but thirty-six amendments, chiefly in very minor details, the fundamental law of the Commonwealth. ${ }^{11}$

This Massachusetts constitution, drafted by John Adams and his associates, was and is very far removed in its character from the cumbersome instruments adopted in recent times. A bill of rights, a statement of the mode of election or appoimtment and of the organization of the departments of government, a few general provisions in regard to the writ of habeas corpus and the like, these constitute the entire instrument. No elaborate provisions designed to make men honest by statute, such as the provisions found in our California Constitution forbidding special legislation, ${ }^{12}$ or requiring bills to be properly entitled so as not to mislead, ${ }^{13}$ or requiring judges to take an oath that they have diligently decided all cases before drawing their salary, ${ }^{14}$ or requiring them to render their opinions in writing, stating the reasons. ${ }^{15}$ There are not even found in this constitution any provision for the independence of the judiciary, such as is found in the federal constitution, forbidding the legislature from reducing the judges' salaries during their term of office. On the contrary the judges are made amenable to legislative discipline; the governor may remove them "upon the address of both houses of the legislature." Their jurisdiction and powers are wholly in the hands of the legislature to fix and determine. ${ }^{16}$ In fact, the distinguishing feature of this ancient and honorable document lies in the fact that it leaves to the legislature absolute power, subject only to the bill of rights, to legislate freely upon every subject demanding legislation.

The same characteristics which mark the Massachusetts document, attach to the federal constitution adopted seven years later. Here, too, we find the simple outline of the frame of government and the same willingness to trust the legislative department which we found in the colonial constitution of Massachusetts. The powers granted to Congress were wisely described in the broadest language, the limitations on its powers were few and such as were imperatively demanded to carry out a federal

\footnotetext{
11 For the amendments, see 3 Thorpe, 1911-1921.

12 Constitution of California, Art. IV, sec. 25.

13 Id., Art. IV, sec. 24.

14 Id., Art. VI, sec. 24.

15 Id., Art. VI, secs. 2, 24.

${ }_{16} \mathrm{On}$ the tenure and powers of judges, see. Massachusetts Constitution, Part the Second, Chap. III.
} 
union. Indeed, the framers of the federal instrument were willing to go further than even John Adams had done in entrusting power to the legislature. They onitted even to reserve to the people the rights which the traditions of English and Colonial history had taught them to regard as inviolable. Madison and Wilson and Hamilton were willing to leave the protection of these rights to public opinion; they knew that they were as safely guarded by the hearts and sentiments of the people as by being written on tablets of stone or bronze. No modern government, even at the end of the eighteenth century, would dare to hold a person to answer a serious crime without an indictment, or to quarter soldiers upon the people in time of peace. If a legislature or executive could be found so bold as to usurp such unusual powers, the great statesmen and political philosophers who guided the convention, knew that a paper constitution would be powerless to withstand the tyranny.

How the states refused to ratify the constitution unless these fundamental guarantees were added is familiar history. Whether the result of the first ten amendments demanded by the States as a condition of ratification, has been an unqualified blessing many might doubt, though not inclined to be severe critics. That the jury in federal courts must render unanimous verdicts, ${ }^{17}$ that it must consist of twelve inen, ${ }^{18}$ that criminal proceedings must be by common law indictment, ${ }^{19}$ is due to the fact that these things are demanded by the bill of rights. Only a few months since, the Supreme Court of the United States held that a federal court could not, though the evidence was all in favor of the defendant, set aside a verdict in favor of the plaintiff and direct one for the defendant,-though the state courts were doing this thing continually,--because the fifth amendment provides that no fact tried by a jury can be reexamined in any court of the United States, except according to the rules of the common law. ${ }^{20}$ Such examples as these at least raise the question whether the framers were not right in deciding to leave such matters to the force of public opinion rather than to tie the hands of posterity by formal

17 Reynolds v. U. S., (1878) 98 U. S. 145.

18 Thompson v. Utah, (1898) 170 U. S. 343; Capital Traction Co. v. Hof, (1899) 174 U. S. 1. After Utah became a State, it could provide for trial by a jury of eight. Maxwell v. Dow, (1900) 176 U. S. 581. $19 \mathrm{Ex}$ parte Wilson, (1885) 114 U. S. 417.

${ }^{20}$ Slocum v. New York Iife Ins. Co., (1913) 228 U. S. 364. 
enactment in the shape of a higher written law. Might not the beneficial results that have doubtless accrued to the people of the United States from the fact, as Mr. Bryce says, that "the democratic man (as Plato would call him) is pleased to read and know his constitution," have been equally well secured had the bill of rights been declared in the form of a statute, instead of having been enacted in the form of a law practically impossible of amendment, save in the case of notorious failure?

If we contrast these early specimens of written constitutions with those adopted in more recent years by the States, we are at once impressed by the fact that the theory of the purpose of a constitution has wholly changed. ${ }^{21}$ From being a mere scheme or plan of government, the constitutions of later time have become, in large part, codes of statutory law,-if the word "code" can properly be applied to such formless and unsystematic instruments. Indeed, so far has this tendency upon the part of the people to enact legislation in the form of constitutional amendments extended, that courts have been obliged to recognize the phenomenon, and to change their theory of constitutional interpretation. The older doctrine of the courts was that the constitution of a state merely provided limitations upon the powers of the legislature, the executive and the courts. For example, under the first constitution of California, as amended, a clause providing for a liability upon stockholders in a corporation was, on this theory of interpretation, held to be merely a mandate to the legislature, and not self executing. ${ }^{22}$ In a later case, however, arising under the constitution of 1879 , a somewhat similar provision with respect to the liability of directors was held to be self executing. Mr. Justice Temple said in the last named case:23

"When the federal constitution and first state constitutions were framed, the idea of a constitution was that it merely outlined a government, provided for certain departments and some officers and defined their functions, secured some absolute and inalienable rights to the citizens, but

21 On the later constitutions in general, see Parry, Modern State Constitutions, 23 Mag. Am. Hist. 152; Constitutional Reform in the States, 121 North Am. Rev. 1; Bryce, American Commonwealth, v. I, pp. $413-415$, and Dodd, The Revision and Amendment of State Constitutions.

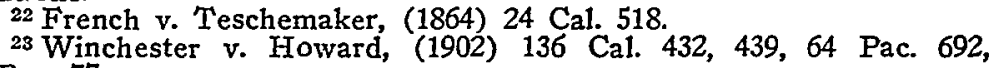

69 Pac. 77. 
left all matters of administration and policy to the departments which it created. The law making power was vested wholly in the legislature. Save as to the assurances of individual rights against the government the direct operation of the constitution was upon the government only. And such assurances were themselves in part but limitations upon governmental powers. Latterly, however, all this has been changed. Through distrust of legislatures and the natural love of power, the people have inserted in their constitutions many provisions of a statutory character. These are, in fact, but laws made directly by the people instead of by the legislature, and they are to be construed and enforced in all respects, as though they were statutes. . . . Under former constitutions its was natural that the court should presume that a constitutional provision was addressed to some officer or department of the government, or that it limited the power of the legislature, or empowered and perhaps directed certain legislation to carry into effect a constitutional policy. Now, the presumption is the reverse. Recently adopted state constitutions contain extensive codes of law, intended to operate directly upon the people as statutes do. To say that these are not self executing may be to refuse to execute the sovereign will of the people. . . . I should say the rule now is that such constitutional provisions must be held to be self executing when they can be given reasonable effect without the aid of legislation, unless it clearly appears that such was not intended."

Several stages may be traced in the process by which the state constitutions have ceased to be constitutions in the true sense and have become codes of popular law. The first stage is represented by the federal constitution as it left the convention for ratification by the states, - a mere skeleton of government, leaving the various departments, and particularly the legislative department, practically unhampered by positive restrictions. The theory of the proper scope of a written constitution, expressed by the framers of the federal constitution never found complete expression. The instrument, as finally ratified by the states, contained the first ten amendments, and as finally adopted may, therefore, be said to typify the second stage of the evolution of the written constitution.

The theory of those who insisted upon the insertion of the 
bill of rights was that certain furdamental rights, the result of the long struggle in England between the people and the crown, must be protected against possible encroachment. Everybody conceded the importance of these rights of the people. The only difference of opinion was as to whether they were not so basic and elemental in character that they might not, like the fundamental principles of morality, be omitted from the written constitution. No written law is or can be complete in itself. Our own civil code, for example, falls far short of stating the law as it actually is. The whole system of equity, the important doctrine of estoppel, which is in fact, a new sort of equity made necessary by the ossification of equitable principles as administered by courts, are not stated and probably cannot be stated in the form of a code, though they must exist over and beyond the written law. A literal or purely logical interpretation of written language is often intolerable. And the courts or administrative officers interpreting law necessarily resort to principles of convenience and natural justice. Had the bill of rights been omitted from the federal constitution, it is not probable that any of the particular rights guaranteed by these amendments would have been, in any marked degree, violated by legislatures, public officials or courts.

The example of the first ten amendments doubtless accustomed people to the theory that the right way to avoid an evil was to pass a constitutional amendment. The stage represented by this theory we may call the third stage in the evolution of the modern state constitution. Direct limitations upon legislative power mark this period of the history. Those who framed the original amendments to the federal constitution did not have in mind a direct limitation on the powers of their Congress. They were seeking to reserve rights to the people rather than to forbid legislation. Probably it never occurred to many of those who demanded the insertion of these fundamental guarantees that they were, to some extent, limiting the powers of their own representatives. They feared the encroachment of the executive, not of the legislative department. Consequently, we find that in nine of the ten amendments, the language is not language of direct limitation. Only in the first one, respecting religious freedom, do we find the words "Congress shall pass no law;" everywhere else the limitations are implied rather than express,-for example, "no person shall be deprived of life, liberty or property 
without due process of law." But in the period of which we are now speaking, there is no mere implication of a limitation on the legislative powers. The language used could not be more express than it is. Take, for example, sec. 25 of Article IV of the present Constitution of California, "The legislature shall not pass local or special laws in any of the following enumerated cases." Then follow thirty-three subdivisions, the last of which reads, "In all other cases where a general law can be made applicable." Other prohibitions in the California Constitution extend to the minutest details, - the legislature is forbidden to authorize lotteries; ${ }^{24}$ only certain amounts can be expended by the legislature for clerks; $;^{25}$ judges of the appellate courts must deliver their opinions in writing $;^{26}$ acts passed by the legislature must embrace only one subject which must be expressed in the title. $^{27}$ The people in this period seem to have forgotten all principles of the mechanics of government. They doubtless would not consent in express words to permit one man to veto absolutely the popular will or the will of the popular legislative assemblies, not even the governor is trusted to do that. But, in effect, by requiring, for instance, that a law shall embrace but one subject, they trust a few judges,-possibly, but one judge upon a division of the Supreme Court,--to determine what is "the same subject," and to annul the act of the legislature by declaring it violative of the constitutional provision. And yet these judges, to whom is given the absolute power of setting aside legislation, are themselves so little trusted that they must take an affidavit that they have been diligent before they can draw their salaries, ${ }^{28}$ and cannot decide the simplest question of law without giving a written opinion stating the reasons for their decision. ${ }^{29}$ The responsibility of passing bad or dishonest legislation is taken off of the shoulders of those who have passed it, and it is left to the courts to destroy it. Unfortunately, however, the courts cannot consider whether it is bad or dishonest. The best and most carefully considered legislation must fall equally with the worst and most ill-advised if it violates the provision that a statute

24 Constitution of California, Art. IV, sec. 26.

25 Id, Art. IV, sečs. 23 and 23a.

26 Id., Art. VI, secs. 2, 24.

27 Id., Art. IV, sec. 24.

28 Id., Art. VI, sec. 24.

29 Id., Art. VI, secs. 2, 24. 
must embrace but one subject. The people in this stage of constitution making seem to say: "We have found our servants dishonest; we won't discharge them and try to get honest and competent ones. No, we will continue to employ those who have been proved to be bad, but we will take good care to tie their hands securely so that they can neither steal nor work."

If the legislature is hampered so that it cannot legislate, what must be the result? The people must themselves legislate. This has been the case with increasing frequency in California for thirty years. Recent constitutional amendments have, for the most part, been merely statutes, of greater or less importance. This period may be called the fourth stage of constitutional development. If a man, or a group of men,-for it is a fact that popular government must acknowledge that all legislation is in, a sense, the work of an individual or small group of individuals, ${ }^{30}$-desire important legislation to be adopted, under a constitution such as that of California he or they will take no chances of steering it through the rocks and dangerous shoals of legislative action. The simpler and easier process is to submit the law to the people as a constitutional amendment. In this way, such important matters as the establishment of the railroad commission, ${ }^{32}$ the taxation of public utilities, ${ }^{32}$ the authorization of workmen's compensation legislation, ${ }^{33}$ have in recent years been passed. Even such matters as those involving considerable financial interests, such as the issuance of special bonds for harbor improvennents ${ }^{34}$ or providing for the Panama Pacific Exposition, ${ }^{35}$ are covered by special constitutional amendments. There is on the face of it, no particular objection to such matters being placed in the constitution. The people are only trying to get out of the bog of legislative inefficiency created by the constitutions and constitutional amendments adopted in the preceding period. But they are using a cumbersome process. The machinery is quite disproportionate, in many cases, to the result to be accomplished. It is like using a trip-hammer to crack a nut. And we must not forget that while the constitutional provisions of these days are,

\footnotetext{
${ }^{30}$ Dicey, Law and Public Opinion in England, p. 21.

31 Constitution of California, Art. XII, secs. 20, 21, 22 and 23.

32 Id., Art. XIII, sec. 14.

${ }^{33} \mathrm{Id}$., Art. XX, sec. 21.

34 Id., Art. XI, sec. 18.

35 Id., Art. IV, sec. 22 and Art. XI, sec. 8a.
} 
as Mr. Justice Temple said, in effect statutes, they are statutes of a higher and controlling quality. While the people are legislating through the form of constitutional amendments concerning taxation, they may be affecting action in some remote sphere of legislation. The legislature, it is conceivable, may be forbidden by some provision in the general taxation amendment from authorizing a municipality of the sixteenth class to buy a fire engine. Greater freedom of legislative action would be secured if such purely statutory matters could be expressed in the form of what they are in substance, namely, statutes.

The most modern invention in constitution making is one that was bound to result from the two preceding stages. The people in this fifth and latest period of constitutional evolution are by indirection restoring to the legislature some of the powers which they took away during the third period,-the period of legislative limitation. Direct legislation, through the instrumentality of constitutional amendment, is subject to the difficulty that if the legislation proves unworkable in practice or defective in detail, it inust nevertheless await the rather slow and. cumbersome process of further constitutional amendment. Why not provide that any additions or changes necessary in details be left to the legislature, with the provision in the constitutional amendment itself that such changes shall not be held unconstitutional by any tribunal or department of the government? In the recent amendments to the California Constitution establishing the railroad commission, accordingly, we find a provision that the legislature may at its pleasure confer additional powers upon the commission, even though they conflict with other provisions of the constitution itself. $^{30}$ In other words so far as the Constitution of the State is concerned, the legislature, might, if it chose, confer upon the railroad commission power to carry out the death penalty without trial, or confiscate an obnoxious person's property in the same manner. ${ }^{37}$

${ }^{36}$ Art. XII, sec. 22. "No provision of this constitution shall be construed as a limitation upon the authority of the legislature to confer upon the railroad commission additional powers of the same kind or different from those conferred herein which are not inconsistent with the powers conferred upon the railroad commission in this constitution, and the authority of the legislature to confer such additional powers is expressly declared to be plenary and unlimited by any provision of this constitution."

${ }^{37}$ See opinion of Henshaw, J., in Pacific Telephone and Telegraph Company v. Eshleman, (Dec. 20, 1913) 46 Cal. Dec. 551, 562-563. The constitution of the United States, of course, would forbid such absurd 
Theoretically, this is possible. But it is also theoretically possible that the immigration officials of the federal government might exclude one of our most prominent citizens returning from a European trip upon the ground that he was an alien within the classes forbidden entrance to our country by the immigration laws, and that their action if based on a hearing and some evidence would be incapable of review by the courts. ${ }^{38}$ Or our most important business might be denied the use of the mails by the postal authorities, without redress. ${ }^{39}$ Why do not such things happen in practical experience? First, because public officials are usually persons possessing some common sense. Secondly, because the force of public opinion would destroy any tribunal or officer which sought to act in such a tyrannical manner.

What then, in view of such a provision as sec. 22 of Article XII of the Constitution of California, becomes of our written constitution with its elaborate system of checks and devices for preventing unjust or oppressive legislation? Can any one doubt but that the practice initiated by the authors of the railroad commission amendment will be extended to other important legislation,-ultimately, even to legislation of comparatively little importance. The railroad commission amendment is even now not the only clause of our constitution which seeks to lift important legislation outside of the limitations imposed by the written constitution. The provisions of sec. 2I of Article XX, authorizing workmen's compensation laws, permit the legislature to confer the power of settling questions arising under such laws "by arbitration, by an industrial accident board, by the courts, or by either, any or all of these agencies, anything in this constitution to the contrary notwithstanding." The singular phenomenon of regranting to the legislature by special clause in the constitution powers which were formerly taken away, and which are still withheld for most purposes, must finally result in striking off all

consequences as those supposed in the text. It must, however, be remembered that the power of the Supreme Court of the United States itself to declare laws unconstitutional exists only by virtue of the fact that Congress has provided a means of review. It is competent for Congress to qualify the power of the Supreme Court in stuch way as to withdraw it in particular classes of cases. See, Constitution of the United States, Art. III, sec. 2: 1 Willoughby, Constitution, p. 976; Ex parte McCardle, (1868) 7 Wall. 506.

38 United States v. Ju Toy, (1905) 198 U. S. 253.

39 Public Clearing House v. Coyne, (1904) 194 U. S. 497. 
shackles on legislative powers, other than those imposed by public opinion. The written, rigid constitution would seem to be inevitably doomed.

Another development in recent history seems to spell the destruction of the rigid constitution,- - the introduction of the referendum and initiative. Though formally adopted only in I9II these devices have practically been in force for many years. The one hundred and one amendments to the constitution of 1879 from I884 to IgII were for the most part but "people's laws"; the twenty-three amendments submitted to the voters of California to be voted upon at the next election are of the same character,-statutes which the promoters desire should not be subjected to the tests of constitutional law. ${ }^{40}$ The great majority of the one hundred and one amendments passed in twenty-seven years were of comparatively small importance, but were adopted in the form of amendments because those interested in the legislation feared it might be in excess of legislative powers; they shunned the Scylla of special legislation, the Charybdis of formalities imposed upon legislative action. Lawyers and students of governmental forms may lament the fact that our modern constitutions are huge and undigested codes of statutory law, but practical men will not trust their legislative efforts to the dangerous sea of constitutional law. The problem is much the same as that which confronts the administration of our legal procedure. If lawyers have the power, through the insufficient control exercised by an elective judiciary over the conduct of the bar, to raise points which may possibly serve their client,-though the possibility may be very remote,-can it be doubted that they will take advantage of the slightest technicalities in their client's behalf? The difference in practice

40 The figures are taken from the Report of the Section on Constitutional Amendments of the California State Bar Association, 1913, of which J. A. Gibson, of Los Angeles, was chairman. The first amendments were adopted in 1884. More than two-thirds of the entire number of amendments to the California Constitution were made in the thirteen years from 1898. Up to 1898 there had been thirtyfive amendments proposed, some of which had not been adopted. Dodd, Revision and Amendment of State Constitutions, 268. That the practice of direct legislation through constitutional amendment is not confined to California appears from the fact that during the period from 1899-1908, 472 amendments to the State constitutions were submitted to the people. Dodd, Revision and Amendment of State Constitutions, p. 269. See the whole of chapter V of this scholarly and practical work for information upon this subject. 
between the English bar and our own, in this respect, is not due to the fact that the one is superior to the other in character or ability. It is rather that the English judge's independence of the bar enables him to control the efforts of counsel.

If we are to give direct legislation a fair trial, it is high time to investigate the relations of the written constitution of the State towards such legislation. If the people pass a referendum measure of the utmost importance, shall the courts declare it unconstitutional, because, for example, the judges believe that it involves a gift of the public money, or because it constitutes special legislation? Their oaths of office require them to do so, if the constitution contmues to remain in the future, as it has been in the past, a law of higher character than other statutes. And not only the courts, but the executive officers of government, treasurers, auditors, boards and commissions must, like the courts, determine whether the latest expression of the popular will established by the referendum, or the earlier expression in the constitution shall be controlling. Too great a responsibility is, it is submitted, placed upon the subordmate agent, if he is obliged to set aside the acts of his principal. We cannot conceive of a private business being conducted upon such a principle; it is no more workable in government than in business. A proper test of direct legislation demands an open field, bounded only by the limits set by the federal constitution.

Another difficulty arises, or will arise, in connection with the working of a written constitution in its relation to direct legislation. It is safe to predict that the law passed under the referendum or initiative provisions will itself partake of the character of constitutional law. If an inconsistency should exist between a legislative act and a referendum law, though earlier in date, those upon whom devolves the duty of interpreting or administrating the laws, will, it is safe to say, very properly reject the legislative act in favor of the referendum. The servants of the law must instinctively feel that the "people's law" is, to use a Hibernicism, more supreme than the legislature's though, perhaps, less supreme than the "people's law" expressed through the process of constitutional amendment. There will thus be developed intermediate the present constitutional system and the legislative law, another system partaking of the characteristics of constitutional law of a subordinate grade.

What will be the consequences of such a system? A probable 
result, we venture the suggestion, will be greater inefficiency on the part of the legislature in answering the demands of public opinion. The system of written constitutions with elaborate schemes for preventing legislation was bad enough. It has been sufficiently difficult for legislators, from the farm or factory, or even from the legal profession, to answer the questions which every legislator must ask himself under the general American constitutional system before he can conscientiously or intelligently determine whether or not proposed legislation will stand the test of constitutionality. Little wonder that social legislation in spite of the force of public opinion has been more delayed in the United States than elsewhere; little wonder that property, which Burke calls the "sluggish, inert and timid" principle in government, should have been unduly represented at the expense of ability, which he terms the "vigorous and active principle." It is, accordingly, not surprising that, while nations which we are accustomed to regard as unprogressive, such as Russia or Servia, many years since adopted legislation with respect to employer's liability, it is only within the last few years that the states of our Union have undertaken to pass such laws. The possibility of the enactment of such laws has, it is true, been discussed for many years in legal and other periodicals. But some of those best informed upon the subject of constitutional law believed that the police power of the state would not protect such legislation. Their prophecies have in most cases been disproved. Nevertheless the question remains, how long was the legislation delayed by the fear of the inability to legislate? Much criticism, in large part unjust, has been directed towards the courts, because they have destroyed legislation as conflicting with constitutional provisions. The evil done by the courts in this respect is as naught compared with the inertia and political apathy that has resulted from the fear that this or that suggested statute might prove unconstitutional. When students of government and constitutional law and leaders of public opinion hesitate even to propose improvements in existing law because of possible doubt as to their validity, such improvements must come, if they come at all, from the less competent and less law respecting portion of the community.

If public opinion was so extensively hampered in its expression through the existence of the written constitutions of the state before direct legislation was introduced into our system, 
the problem of moulding and administering law by the legislature and governmental departments is made vastly more complicated by the presence of the "people's law." The legislator or the executive official will now not only have to answer the questions whether the law may not violate the constitution of the State or the constitution, laws and treaties of the United States. He must also determine whether it may not be inconsistent with antecedent "people's law," and if he determines that it is, he must then determine whether or not the "people's law" does not itself conflict with the constitutional law of the State or of the United States. If instead of a state legislator, we descend to a councilman under a charter, the problem is many times complicated. He must consider whether the proposed measure is affected (I) by the local charter, (2) by the general laws passed by the legislature, (3) by the "people's law," (4) by the law of the state constitution, (5) by the law of special commissions placed above the State constitution, (6) by acts of Congress and treaties of the United States, and (7) by the constitution of the United States. Not only must the possible conflicts between the proposed law and each of these laws be taken into account, but the relation of each subsidiary sort of law to all that is superior to it in the hierarchy of laws, must also be determined. For example, if a general law conflicts with a local charter the councilman should also determine whether the general law itself is not invalid by reason of being in conflict with the "people's law," and with the four systeins above it. Any one interested in mathematical problems may easily estimate the combinations resulting from this confusion. We are establishing a hierarchy of laws comparable with the worst political or religious hierarchies of the past, and this in a nation which, of all others, best claims to be democratic.

One or the other of two things must happen, either the "people's law" will be lifted to the plane of constitutional law or constitutional law will be degraded to the plane of "people's law." Unless very radical changes are made in the constitution, it is safe to predict that "people's law" will raise itself to the level of constitutional law. The framers of important measures, or of measures which seem to them to be important, will not trust their proposals to the legislature or even to an inferior sort of initiative when they can employ a direct initiative by constitutional legislation. ${ }^{41}$ The present shadowy line of demarcation between

41 Constitution of California, Art. IV, sec. 1. 
direct legislation and constitutional law will, it is safe to say, disappear, and the so-called constitution will be as easy of amendment as the so-called "people's law." 42 But over and beyond this, can it be doubted that those interested in what they deem important legislation will lift it entirely beyond and above the realm of constitutional law by the device adopted in the workmen's compensation and railroad commission amendments?

Unless the legislature is restored to its original position of imdependence and supremacy, we shall be flooded with a mass of ill-advised and ill-digested legislation wrought out in all of its details by persons not equipped for the purpose of drafting laws. We shall have referendum and initiative statutes conflicting with prior statutes of the same sort, with provisions of the State Constitution, with acts of the legislature. If direct legislation is not to lead to confusion worse confounded, we must arrange it in some way that only the broadest outlines of the popular will shall be expressed in the "people's law," and the working out of the details left to the legislature. Undoubtedly, that body should be reformed,-obviously, at least, in the way of reducing the number of members,-but the discussion of such reform is aside from the purpose of this paper. The point here urged, and the only point, is that the legislature, whatever its constitution should be given full power to make law with full responsibility to the people for its exercise. If it is the temper of the people, as indicated in the most recent amendments, to place executive commissions and their acts outside of the constitution, why not simplify the whole matter by putting in the hands of the most important delegated agency of the people, the power to legislate freely? Surely, an instrument that has been amended one hundred and one times in twenty-seven years, can hardly with justice be called an organic law. Nor can one which is capable of amendment by initiative vote be said to act as a check upon the dangerous passions of the mob.

The whole theory of checks upon legislative power has under these recent amendments, entirely broken down. As said by $\mathrm{Mr}$.

t2 Upon the tendency in constitution making to increase the facility of amendment, see Dodd, Revision and Amendments of State Constitutions, p. 129. 
Justice Henshaw in the case of Pacific Telephone and Telegraph Co. v. Eshleman, ${ }^{43}$ speaking of the railroad commission amendment, "While it is perhaps the first instance where a constitution itself has declared that a legislative enactment shall be supreme over all constitutional provisions, nevertheless this is but a reversion to the English form of government, which makes an act of Parliament the supreme law of the land." 44 We must frankly recognize the fact, whether we like it or not, that we are living under a democracy practically unrestrained save through the force of public opinion and the limitations of the federal constitution. Indeed, we have been governed for years before we openly recognized the fact, by a system of direct legislation in a disguised form. Artificial and mechanical barriers cannot keep out the flood. The pernicious theory that we can secure good legislation by putting shackles upon our legislatures should be and is being abandoned. Legislators must be treated as responsible human beings, not as children or criminals, and in view of recent developments, it is safe to say that they will be so treated.

Those who still retain some trust in written limitations need not despair. The federal constitution still stands and will doubtless continue to stand for many years as an artificial restraining influence upon hasty or unjust laws. In the future as in the past, the restraints on legislative power found in the fourteenth amendment will control state action. So long, in fact, as the federal system lasts and the central power continues to encroach upon the power of the states, there is little danger that this amendment will be substantially changed. The will of the nation will continue to be superior to the will of the individual states.

4346 Cal. Dec. 551, 562.

14 Mr. Justice Henshaw's statement that this is the first example of statutory law made superior to constitutional provisions is strictly correct, but it should be noticed that there are American state constitututions where constitutional law is equal to statutory law. See, e. g., the Constitution of Delaware of 1897 , which does not require a popular vote upon amendments, but simply the action of two successive legislatures. Dodd, Amendment and Revision of State Constitutions, p. 135. No constitution has ever been adopted in that state by popular vote. Id., p. 70. Former constitutions of Maryland and South Carolina also provided for amendment by the legislature alone. Id., p. 121. 
In the vague phrases of this amendment, substantially embodying the essential principles of the bill of rights, but more flexible because of the generality of expression, a powerful weapon exists to extend the federal power by limiting the power of the states.

The more subtle results in the effect upon our character and habits of political thought through the simplification of government by the abolition of the restraints on legislative power are not to be overlooked. It is impossible, of course, accurately to weigh these results. But who can doubt that the constant habit of recurring to written constitutions in connection with changes in the law, has conduced to breed in the minds of many of us a tendency to regard the text rather than the spirit, to substitute the mere question of legality for the question of expediency or right. If the question is whether injunction shall be permitted against labor unions, to take an example at random, how is the question met? Many, if not most legislators opposed to the measure upon what seem to them valid grounds of policy or justice, take refuge behind the declaration that the legislation is unconstitutional. Even an honest man can readily convince himself of the impossibility of doing that which he does not thimk right or expedient. Can anyone doubt that it would be better to force the debate into the open, to require the disputant to argue the case upon its merits rather than upon technicalities? And it is not only members of Congress and of state legislatures, who take refuge, often unconsciously, under the excuse that undesired legislation is unconstitutional, but the people themselves often substitute the form for the substance. How many voters, some years ago, were driven to support the protective tariff by reason of the fact that the platform of the Democratic party declared it to be in violation of the Constitution? The discussion of the question was diverted from the ground of policy to that of legality, and many voted for the tariff, though not convinced of its value, because they knew that it was not void on legal grounds. To the habit of American lawyers and judges in the past to give more attention to literal interpretation than do the English lawyers or judges,- to read statutes, as Mr. Chesterton says, with an "unspiritual spirit,"-is, perhaps, in part due to the constant reference to the higher written law. An elaborate written scheme leaves little to the legal or political imagination,-just as important a quality with the lawyer or public man as the poetical or scientific imagination with the poet or the scientist. 
The effects of written constitutions upon our political character has often been noted by profound students of our institutions. ${ }^{45}$ One of the best statements is probably that made by the greatest of our constitutional lawyers, James Bradley Thayer. $\mathrm{He}$ says : ${ }^{46}$

"No doubt our doctrine of constitutional law has had a tendency to drive out questions of justice and right, and to fill the minds of legislators with thoughts of mere legality, of what the constitution allows. And, moreover, even in the matter of legality, they have felt little responsibility; if we are wrong they say, the courts will correct it. Meantime they and the people whom they represent, not being thrown back on themselves, on the responsible exercise of their own prudence, moral sense and honor, lose much of what is best in the political experience of any nation, and they are belittled as well as demoralized. . . . The checking and cutting down of legislative power, by numerous detailed prohibitions in the constitution, cannot be accomplished without making the government petty and incompetent. This process has already been carried much too far in some of our states. Under no system can the power of courts go far to save a people from ruin; our chief protection lies elsewhere."

What Professor Thayer means, of course, is that the sole protection and support of the modern state lies in public opinion. That opinion made and expressed through newspapers and journals, through trade and labor organizations, through universities and churches, through public discussion, must harmonize with the state, or the state must perish. "As force is always on the side of the governed," says Hume, "47 "the governors have nothing to support them but opinion. It is, therefore, on opinion only that government is founded; and this maxim ex-

45 Bryce, American Commonwealth, 1st ed., vol. I, p. 377 (cited in Thayer, Legal Essays, p. 39 note.) Other authorities cited by the editor of the last named book, Dean Ezra Ripley Thayer, in the note referred to, are Judge Hare, le Comte de Franqueville, Justice Story, Chief Justice Shaw, and "The Federalist."

${ }_{40}$ Thayer, Origin and Scope of the American Doctrine of Constitutional Law, in Thayer, Legal Essays, pp. 38-39.

${ }^{27}$ Hume, Essays, vol. I, Essay IV (cited by Dicey, Law and Public Opinion in England, pp. 1-2.) 
tends to the most despotic and most military governments as well as to the most free and most popular. The Soldan of Egypt or the Emperor of Rome might drive his harmless subjects like brute beasts, against their sentiments and inclination; but he must, at least, have led his mamelukes, or praetorian bands, like men, by their opinion."

A final quotation from Burke brings to a focus all that has been attempted to be brought out in this rambling paper. "It is better to cherish virtue and humanity, by leaving much to free will, than to attempt to make men mere machines and instruments of a political benevolence. The world on the whole will gain by a liberty, without which virtue cannot exist."

Berkeley, California.

ORRIN K. McMurRay. 